\title{
OBE-Based College English Curriculum Design and Teaching Practice in Dalian Neusoft University of Information
}

\author{
Sun Jianhua \\ No. 8 Software Park Rd. Dalian. P. R. China \\ sunjianhua@neusoft.edu.cn
}

Keywords: Outcome-Based Education, College English, Dalian Neusoft University of Information.

\begin{abstract}
Nowadays, Outcome-Based Education (OBE) has gained increasing prominence in China and it has been formally implemented among all schools of Dalian Neusoft University of Information (DUI). One of the key concepts of OBE is that teaching should be driven by outcomes that are desirable for students, and that teaching and assessment are adjusted to serve the goals of the expected outcomes. The essay reports on a curriculum design and teaching practice in the curriculum of College English for non-English majors under the guidance of OBE in School of Foreign Language, DUI. The findings suggest that both the students and the teachers hold a generally positive attitude towards OBE, but there are still plentiful of issues concerning the successful implementation of OBE at curriculum level. It is hoped that this study will shed some light on how OBE can be implemented successfully at curriculum level in the future.
\end{abstract}

\section{Introduction}

Outcome-Based Education (OBE) can date back to the 1980s, as a tool to facilitate educational renewal, "basing what we do instructionally on the outcomes we want to achieve" (Spady, 1988, p.5). It has been promoted internationally in such countries as the United States, Australia, China and South Africa. In response to the changes and challenges of the current higher education, new educational concepts and methodologies should be adopted to ensure the quality of education. Since 2016, Dalian Neusoft University of Information (DUI) has formally implemented OBE reform among all schools including School of Foreign Languages. With two-year experiences of curriculum design and teaching practice under the guidance of OBE, the new teaching model of College English has been widely accepted and welcome by the students and teachers.

\section{Outcome-Based Education: Theory and Practice}

William Spady is regarded as the world authority on OBE. He defines OBE as a process of "clearly focusing and organizing everything in an educational system around what is essential for all students to be able to do successfully at the end of their learning experiences.” (Spady, 1994, p.1) There are three aspects about the definition of OBE: first, the outcome is the goal and focus; second, the curriculum is designed according to the output level outcome; and third, it is the responsibility of the teachers to supply appropriate materials and supervision in learning experiences for the success of all students. For Spady, learning is not significant unless the outcomes reflect the complexities of real life and provide prominence to the life roles that the students will face after they have finished their higher education in school.

Killen (2000) further illustrates Spady's idea, emphasizing that outcomes should describe long-term significant learning, with three basic premises which are the students' differences in succeeding, the encouragement of successful learning, and the conditions provided by schools and teachers. As for Harden (2002, p.117), he believes that OBE is featured by: "the development of clearly defined and published learning outcomes that must be achieved before the end of a curriculum; the design of the curriculum, learning strategies and learning opportunities to ensure the achievement of the learning outcomes; an assessment process matched to the learning outcomes and the 
assessment of individual students to ensure that they achieve the outcomes; and the provision of remediation and enrichment for students as appropriate.”

OBE is using outcomes to guide the instructional planning, as what matters ultimately is not what is taught but what is learnt. Therefore, the most desirable learning outcomes are first identified and the curriculum, instructional materials and assessments are created to support the intended outcomes (Spady 1988). It is important to achieve the intended outcomes in a logical and effective manner by what we teach, how we teach, and how we assess. In another word, the teaching and learning activities and the assessment tasks should be in accordance with the intended outcomes, so that all of theses are fully integrated and consistent with one another.

\section{OBE at College English Curriculum at DUI}

Dalian Neusoft University of Information (DUI) has structured OBE in such a way that learning outcomes have been developed at three different levels - the university level, the major level, and the curriculum level. At the university level, the learning outcomes are developed in accordance with university's expectations for all graduates' abilities including knowledge, skills, and qualities at the time of graduation. These outcomes guide the development of major learning outcomes for each major, which further guide the development of curriculum learning outcomes.

In the following sections, the design of learning outcomes as well as the teaching practices of College English for non-English majors at the curriculum level will be discussed in detail, so as to illustrate how such learning outcomes can be properly designed and implemented in the teaching practices under the guiding principles of OBE.

\subsection{Conceive the goals and outcomes}

The goal of College English for non-English majors is to cultivate the comprehensive abilities of the students to meet the demands of major curriculums as well as the future jobs. To achieve the goal, the detailed outcomes of the abilities to be achieved are analyzed and set accordingly. And the current English knowledge and skills are tested in the startup examinations when the students first start their university life. The gap between the goals and the present levels is shown by comparing the outcomes and examination results. Therefore, the goals of the 4 semesters are set for the students with different emphases to achieve in each semester to narrow the gap. And these are set as the outcomes of each semester which are specified in the aspects of listening, reading, speaking, writing and translation. The outcomes are detailed to the quantities of words of the passages for reading writing and translation, and the wpm of the conversations for listening and speaking.

\subsection{Design the curriculum}

At the curriculum level, it is important to design curriculum learning outcomes based on the major learning outcomes, and ensure that the teaching and assessing practices are in accordance with the curriculum learning outcomes. With the goals and outcomes in mind, the processes of the curriculum are designed for teachers to implement the teaching practices. For teachers, instead of focusing on what they should teach, they should think from the students' perspectives and focus on how they can help the students to achieve their learning outcomes in an effective and efficient way. Therefore, to implement OBE successfully in College English curriculum, it is essential to restructure of it to suit the current English levels and learning features of the students. Considering the features of English learning in the era of laptops, pads and smart phones, flipped classes are adopted in the teaching design, which enables the students to acquire the basic and repetitive knowledge by themselves through various media before taking classes. And the class activities are designed to check the learning effects the knowledge and skills which the students have acquired. And they are characterized by such activities as group discussion, presentation and mini projects, representing the real situations for the students to apply what they have acquired into the real life. And the teachers are more of an instructor and supervisor than a lecturer and class controller. And the online resource 
database and exercise database are built for the students to facilitate them to learn, practice and consolidate.

\subsection{Implement the teaching practices}

In the teaching practices, flipped classroom is adopted in the teaching practices with assignments to learn before class, activities on class, and consolidation exercises after class. For College English, at the beginning of each semester, the students are informed of the goal of the semester, as well as those of every unit. And at the beginning of each unit, the students are required to learn about the expected outcomes on the first class, and they can even know it before the first class by reading it on the College English curriculum website. And there are College English learning instruction and requirements for tasks, micro-lecture online videos, documents and courseware for students to learn before each class. And the contents of each unit are divided for students to learn in 8 periods, with 3 periods for listening and speaking, 3 periods for reading and 2 periods for writing and translation. On class, students are required to present the tasks with what they have learnt, and teachers evaluate their performance, point out the problems, and provide suggestions for improvement. After each class, the students are required to finish the consolidation exercises and projects to apply what they have learnt to solve the problems.

\subsection{Assess the outcomes}

To assess the outcomes of the students whether matches the goals, formative and summative assessment measure are adopted in the assessment process. Formative assessment includes the attendance, on-class behaviors, and assignments, assessing the skills and qualities, which accounts for $50 \%$ of the curriculum score. Whereas summative assessment is adopted in the form of test paper to evaluate the outcome of acquiring the knowledge and skills, which account for the other $50 \%$ of the score. After the students finish learning all the contents of each unit, there will be an online quiz to evaluate the students' learning achievements, and the result of each quiz is analyzed to help students find out problems in learning and adjust their learning strategies. At the end of each semester, the scores of summative assessment will be analyzed and compared with those of the former semester to find out the learning effectiveness of the students. And questionnaires are designed and publicized, and forums for students and teachers are also held to learn about their opinions and suggestions for teaching and learning practices. With the analyzed data as well as the opinions from questionnaires and forums, teaching strategies and methodologies are adjusted to better assist the accomplishment of goals.

\section{Summary}

During the 2 years of implementing the OBE teaching practices, students at DUI have improved their own understandings, skills, and abilities in College English. What attracts the teachers and students is that OBE helps them to focus on clearly defined expected learning outcomes, so that they know what exactly they will be able to do after completing the College English curriculum. They are even able to evaluate their own achievement for English in terms of their efforts and time that they have put in English learning and practices. However, the OBE implementation in College English curriculum can be further improved and enhanced. It is an ongoing and evolving process. The university management needs to motivate and promote OBE implementation at all times so that the positive effects can be sustained and therefore the expected objectives can be achieved. All parties concerned, that is, students, teachers, and the university decision-makers and management, should unit and team up in accomplishing the OBE goals and outcomes.

\section{References}

[1] Spady, W. D., Outcomes Based Education: Critical Issues and Answers. Arlington, VA: American Association of School Administration, 1994. 
[2] Spady, W.G., Organizing for results: the basis of authentic restructuring and reform, Educational Leadership, Vol. 46 No. 2, pp. 4-8, 1988.

[3] Killen, R., Outcomes-Based Education: Principles and possibilities. Unpublished manuscript, University of Newcastle, Faculty of Education, 2000.

[4] Harden, R. M., Developments in Outcome-based Education, Medical Teacher, vol. 24, No. 2, pp. 117-120, 2002.

[5] Zhang Yi, Sun Jianhua, College English Teaching Reform Oriented by Internationalized Engineering Talents Cultivation, Language Education, Vol. No. 8, pp. 45-51. 2015. 